\title{
Analisis Kinerja Keuangan Perusahaan Kelapa Sawit yang Go Public di Bursa Efek Indonesia (BEI) Tahun 2013-2017
}

\section{Mohammad Riyanto ${ }^{1}$, Haryati La Kamisi ${ }^{\circledR}{ }^{\bowtie}$, Munawir Muhammad $^{2}$ dan Ekaria ${ }^{2}$}

${ }^{1}$ Alumni Prodi AGRIBISNIS, Fakultas Pertanian, Universitas Muhammadiyah Maluku Utara. Ternate. Indonesia, Email : kamacelo90@gmail.com

${ }^{2}$ Staf Pengajar Prodi AGRIBISNIS Fakultas Pertanian, Universitas Muhammadiyah Maluku Utara. Ternate. Indonesia, Email : dinati.la@gmail.com, munawirmuhammad2012@yahoo.com, ekaria16@yahoo.com

\footnotetext{
Korespondensi : Haryati La Kamisi, Universitas Muhammadiyah Maluku Utara, Ternate, Indonesia, Email : dinati.la@gmail.com
}

\begin{abstract}
ABSTRAK.
Penelitian ini bertujuan untuk menganalisis kinerja keuangan perusahaan perkebunan kelapa sawit yang go public di Bursa Efek Indonesia, selama 2013-2017 dan menganalisis kinerja keuangan pada harga saham. Penelitian ini dilaksanakan di Galeri Investasi Syariah Universitas Muhammadiyah Maluku Utara. Metode Analisis menggunakan rasio likuiditas, rasio leverage, rasio profitabilitas, rasio aktivitas, $Q$ Tobin's dan Regresi Berganda. Hasil penelitian menunjukkan: (1) Likuiditas (AALI, BWPT, DNSG, GOZCO, JAWA, SIMP \& SMAR) memiliki rasio cepat <1, kecuali LSIP. (2) Leverage (BWPT, DNSG, GOZCO, JAWA memiliki LTDtER > 1 dan AALI, LSIP, SIMP, SMAR memiliki LTDtER <1. 3) Aktivitas (AALI, BWPT, DNSG, GOZCO, JAWA, LSIP, SIMP) memiliki TATO < 1.1 dan SMAR memiliki TATO> 1.1). (4) Profitabilitas (AALI, BWPT, DNSG, GOZCO, JAWA, LSIP, SIMP \& SMAR memiliki ROI <0,3. (5) Nilai Perusahaan (SIMP, SMAR, GOZCO, JAWA memiliki $Q<1$ dan AALI, BWPT, DNSG, LSIP memiliki $Q>1$. Kinerja keuangan dari harga saham yang diprediksi oleh quick ratio, LTDtER, TATO, ROI, dan Tobins'Q menunjukkan bahwa ia memiliki pengaruh signifikan terhadap harga saham dengan tingkat signifikansi 0,000<0,05.
\end{abstract}

\section{Keywords: Financial Performance, Liquidity Ratio, Leverage Ratio, Profitability Ratio, Tobin's $Q$}

\section{PENDAHULUAN}

\subsection{Latar Belakang}

Bursa Efek Indonesia (BEI) atau Indonesia Stock Exchange (IDX) merupakan Pasar Modal dan Obligasi hasil dari penggabungan Bursa Efek Jakarta (BEJ) dan Bursa Efek Surabaya (BES). Perusahaan yang terdaftar di Bursa Efek Indonesia, salah satunya sektor pertanian. Sektor pertanian yang paling berkembang adalah sektor perkebunan khususnya perkebunan kelapa sawit. Beberapa Perusahaan perkebunan yang go publicdi BEI yaitu perusahaan dengan kode saham AALI, BWPT. , DNSG, GZCO, JAWA, LSIP, SIMP, SMAR

Perkembangan harta kekayaan perusahaan perkebunan kelapa sawit dengan kode saham AALI, BWPT. , DNSG, GZCO, JAWA, LSIP, SIMP, SMAR selama tahun 2013-2017 mengalami peningkatan akan tetapi pergerakan harga sahamnya berbanding terbalik, yaitu mengalami penurunan.Indeks harga saham Perusahan tersebut dapat dilihat pada Gambar 1.

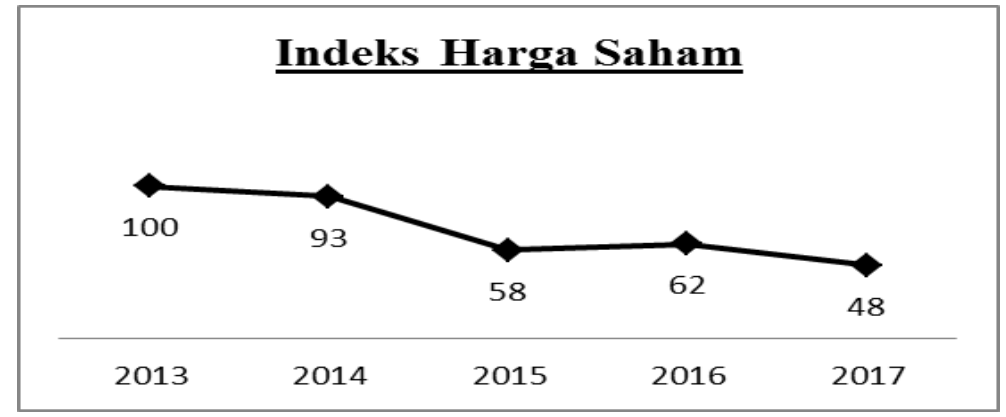

Gambar 1. Indeks Harga Saham

Sumber : Bursa Efek Indonesia, tahun 2013-2018 
Melihat keadaan tersebut, maka diperlukan analisis lebih lanjut mengenai kinerja keuangan guna mendapatkan informasi yang objektif mengenai kondisi mendasar sebuah perusahaan. Alat ukur kinerja keuangan yang dapat dapat digunakan yaitu rasio keuangan dan tobins'q. Rasio keuangan meliputi rasio likuiditas, rasio leverage, rasio aktivitas dan rasio profitabilitas.

Berdasarkan uraian tersebut maka perlunya peneliti menganalisis kinerja keuangan perusahan kelapa sawit yang go public di Bursa Efek Indonesia (BEI) tahun 2013-2017 studi kasus perusahaan yang berkode saham AALI, BWPT. , DNSG, GZCO, JAWA, LSIP, SIMP, SMAR.

\subsection{Tujuan Penelitian}

Tujuan penelitian ini adalah

a. Menganalisi kinerja perusahaan dengan kode AALI, BWPT. , DNSG, GZCO, JAWA, LSIP, SIMP, SMAR selama tahun 2013 - 2017 berdasarkan analisis rasio keuangan dan Tobin's Q?

b. Menganalisis interpretasi kinerja keuangan terhadap harga saham

\section{METODE PENELITIAN}

\subsection{Lokasi dan Waktu}

Penelitian ini dilaksanakan di Galeri Investasi Syariah Universitas Muhammadiyah Maluku Utara selama bulan November - Desember tahun 2018.

\subsection{Sampel}

Metode pengambilan sampel dengan teknik purposive sampling. Pertimbangannya adalah laporan keuangan menggunakan satuan mata uang rupiah. Perusahaan yang telah terdaftar dibawah tahun 2014. Perusahaan menyediakan alamat website dan dapat diakses. Berdasarkan studi awal, sehingga terdapat 8 perusahaan yang dapat dijadikan sampel yaitu perusahaan dengan kode saham AALI, BWPT. , DNSG, GZCO, JAWA, LSIP, SIMP, dan SMAR.

\subsection{Metode Pengumpulan data}

Metode pengumpulan data dalam penelitian ini dengan metode dokumentasi. Sumber data didapat dengan mengakses pada sistus resmi BEI yaitu www.idx.com.

\subsection{Metode Analisis Data}

Metode analisis data dalam penelitian ini adalah.

\subsubsection{Analisis kinerja Keuangan}

1. Rasio Likuiditas, diprosikan dengan quick ratio/ rasio cepat.

Reeve, dkk, (2010) Rumus :

$$
\text { Quick ratio }=\frac{\text { AsetLancar }- \text { Persediaan }}{\text { Utang Lancar }}
$$

2. Rasio Leverage, diproksikan dengan long term debt to equty ratio (LTDtER)/ rasioutangjangkapanjangterhadapekuitas.

Sujarweni (2017), Rumus :

$$
\text { LTDtER }=\frac{\text { Long term Debt }}{\text { Equity }}
$$

3. Rasio aktivitas, diproksikan dengan total assets turnover (TATO)/perputaran total aset Kasmir (2014) Rumus :

$$
\text { TATO }=\frac{\text { Penjualan }}{\text { Total Aktiva }}
$$

4. Rasio profitabilitas, diproksikan dengan return of Invesment/rasio pengembaalian atas investasi. Kasmir (2014) Rumus :

$$
\text { Hasil Pengembalian Atas Investasi } \quad=\frac{\text { EAT }}{\text { Total Aktiva }}
$$


5. Nilai perusahaan, di proksikan dengan Tobins' Q, Rumus Tobin's Q yang dikembangkan oleh Lindenberg \&Ross (1981)

$$
\mathrm{Q}=\frac{(\mathrm{MVS}+\mathrm{D})}{\mathrm{TA}}
$$

Keterangan

$$
\begin{array}{ll}
\text { MVS } & =\text { Market Value of Shares } \\
\text { TA } & =\text { Total Assets } \\
\text { D } & =\text { Debt (nilai pasar hutang) }
\end{array}
$$

\subsubsection{Pengaruh Kinerja Keuangan terhadap saham}

Pengaruh Kinerja keuangan terhadap saham menggunakan analisis regresi berganda. Persamaan regresi berganda dituliskan sebagai berikut:

$$
Y=\alpha+\beta_{1} X_{1}+\beta_{2} X_{2}+\beta_{3} X_{3}+\beta 4 X_{4}+\beta_{5} X_{5}+e
$$

Keterangan

$$
\begin{array}{ll}
\mathrm{Y} & =\text { Harga Saham } \\
\alpha & =\text { konstanta } \\
\beta 1 \ldots \beta 6 & =\text { Koefisien regresi masing-masing variabel independen } \\
\mathrm{X}_{1} & =\text { Quick Ratio } \\
\mathrm{X}_{2} & =\text { Long Term debt to Equiti Ratio } \\
\mathrm{X}_{3} & =\text { Total Asset Turnover } \\
\mathrm{X}_{4} & =\text { Rate or Return on Invesment/ROI } \\
\mathrm{X}_{5} & =\text { Tobin's } \mathrm{Q} \\
\mathrm{e} & =\text { error } / \text { Variabel Gangguan }
\end{array}
$$

\section{HASIL DAN PEMBAHASAN}

\subsection{Hasil}

Berikut ini Ihtisar keuangan perusahaan kelapa sawit.

Tabel 1. Ihtisar keuangan PT. . Astra Agro Lestari Tbk Tahun 2013-2017 (jutaan rupiah)

\begin{tabular}{|l|r|r|r|r|r|}
\hline \multicolumn{1}{|c|}{ Uraian } & \multicolumn{1}{c|}{$\mathbf{2 0 1 3}$} & \multicolumn{1}{c|}{$\mathbf{2 0 1 4}$} & \multicolumn{1}{c|}{$\mathbf{2 0 1 5}$} & \multicolumn{1}{c|}{$\mathbf{2 0 1 6}$} & \multicolumn{1}{c|}{$\mathbf{2 0 1 7}$} \\
\hline \hline Persediaan & 802.978 & 1.278 .120 & 1.691 .575 & $2,097,204$ & 2.018 .104 \\
\hline Total Aset Lancar & 1.691 .694 & 2.403 .615 & 2.814 .123 & 4.051 .544 & 4.245 .730 \\
\hline Total Aset Tidak Lancar & 13.272 .737 & 16.155 .739 & 18.698 .248 & 20.174 .578 & 20.689 .696 \\
\hline Total Aset & 14.964 .431 & 18.559 .354 & 21.512 .371 & 24.226 .122 & 24.935 .426 \\
\hline Liabilitas Jangka Pendek & 3.522 .133 & 4.110 .965 & 3.759 .265 & 3.942 .967 & 2.309 .417 \\
\hline Liabilitas Jangka Panjang & 941.812 & 2.614 .621 & 6.291 .451 & 2.689 .673 & 4.089 .571 \\
\hline Ekuitas & 10.263 .354 & 11.833 .778 & 11.284 .816 & 17.135 .284 & 18.065 .943 \\
\hline Pendapatan & 12.674 .999 & 16.305 .831 & 13.059 .216 & 14.121 .374 & 17.305 .688 \\
\hline Earning After Tax & 1.903 .884 & 2.622 .072 & 695.684 & 2.114 .299 & 2.113 .629 \\
\hline Market Value Of Share & 39.526 .100 & 38.187 .566 & 24.959 .708 & 32.248 .153 & 25.309 .652 \\
\hline \multicolumn{2}{|c|}{ Sumber : Anual Report AALI tahun $2013-2017$} & & & \\
\hline
\end{tabular}

Sumber : Anual Report AALI tahun 2013 - 2017 
Tabel 2. Ihtisar keuangan PT. Eagle High Plantation Tbk Tahun 2013-2017 (jutaan rupiah)

\begin{tabular}{|l|r|r|r|r|r|}
\hline \multicolumn{1}{|c|}{ Uraian } & $\mathbf{2 . 0 1 3}$ & $\mathbf{2 . 0 1 4}$ & $\mathbf{2 . 0 1 5}$ & $\mathbf{2 . 0 1 6}$ & $\mathbf{2 . 0 1 7}$ \\
\hline \hline Persediaan & 126.428 & 303.714 & 304.138 & 345.648 & 364.316 \\
\hline Total Aset Lancar & 1.250 .013 & 1.615 .006 & 2.796 .883 & 1.377 .424 & 1.139 .336 \\
\hline Total Aset Tidak Lancar & 5.771 .479 & 14.764 .834 & 14.861 .954 & 14.876 .929 & 14.851 .812 \\
\hline Total Aset & 7.021 .492 & 16.379 .840 & 17.658 .837 & 16.254 .353 & 15.991 .148 \\
\hline Liabilitas Jangka Pendek & 1.251 .482 & 3.105 .061 & 3.955 .212 & 2.368 .056 & 2.652 .447 \\
\hline Liabilitas Jangka Panjang & 3.537 .530 & 6.328 .088 & 7.050 .710 & 7.626 .861 & 7.276 .008 \\
\hline Ekuitas & 2.232 .480 & 6.946 .691 & 6.652 .915 & 6.259 .436 & 6.062 .693 \\
\hline Pendapatan & 1.730 .531 & 2.264 .396 & 2.674 .271 & 2.541 .763 & 3.045 .954 \\
\hline Laba Tahun Berjalan/EAT & $(28.209)$ & 194.838 & $(181.400)$ & $(391.367)$ & $(187.791)$ \\
\hline Market Value Of Share & 5.946 .673 & 12.610 .116 & 4.350 .490 & 8.637 .930 & 5.769 .128 \\
\hline Sumber: Anual Report BWP & tahun & $2013-2017$ & & \\
\hline
\end{tabular}

Sumber : Anual Report BWPT. tahun 2013 - 2017

Tabel 3. Ihtisar keuangan PT. Dharma Satya Nusantara Tahun 2013-2017 (jutaan rupiah)

\begin{tabular}{|l|r|r|r|r|r|}
\hline \multicolumn{1}{|c|}{ Uraian } & $\mathbf{2 . 0 1 3}$ & $\mathbf{2 . 0 1 4}$ & $\mathbf{2 . 0 1 5}$ & $\mathbf{2 . 0 1 6}$ & $\mathbf{2 . 0 1 7}$ \\
\hline \hline Persediaan & 676.706 & 712.761 & 717.765 & 675.393 & 588.340 \\
\hline Total Aset Lancar & 1.670 .821 & 2.402 .841 & 2.315 .276 & 1.753 .048 & 1.739 .837 \\
\hline Total Aset Tidak Lancar & 4.250 .234 & 4.771 .647 & 5.537 .999 & 6.430 .270 & 6.596 .228 \\
\hline Total Aset & 5.921 .055 & 7.174 .488 & 7.853 .275 & 8.183 .318 & 8.336 .065 \\
\hline Liabilitas Jangka Pendek & 2.011 .462 & 2.113 .192 & 2.098 .774 & 1.961 .618 & 1.724 .895 \\
\hline Liabilitas Jangka Panjang & 2.231 .048 & 2.767 .965 & 3.247 .480 & 3.517 .359 & 3.361 .431 \\
\hline Ekuitas & 1.678 .545 & 2.293 .331 & 2.507 .021 & 2.704 .341 & 3.249 .739 \\
\hline Pendapatan & 3.842 .182 & 4.898 .479 & 4.425 .060 & 3.942 .024 & 5.159 .911 \\
\hline Laba Tahun Berjalan/EAT & 215.696 & 649.794 & 302.519 & 252.040 & 587.988 \\
\hline Market Value OfShare & 4.345 .385 & 8.160 .845 & 6.359 .100 & 5.829 .913 & 4.621 .531 \\
\hline Sumbr: Anal Reprt DNSG
\end{tabular}

Sumber : Anual Report DNSG tahun 2013 - 2017

Tabel 4. Ihtisar Keuangan PT. Gozco Plantation Tbk Tahun 2013-2017 (jutaan rupiah)

\begin{tabular}{|l|r|r|r|r|r|}
\hline \multicolumn{1}{|c|}{ Uraian } & $\mathbf{2 . 0 1 3}$ & $\mathbf{2 . 0 1 4}$ & $\mathbf{2 . 0 1 5}$ & $\mathbf{2 . 0 1 6}$ & $\mathbf{2 . 0 1 7}$ \\
\hline \hline Persediaan & 16.700 & 15.866 & 50.089 & 13.726 & 36.042 \\
\hline Total Aset Lancar & 283.354 & 206.172 & 257.384 & 148.387 & 209.820 \\
\hline Total Aset Tidak Lancar & 2.917 .751 & 3.026 .472 & 4.706 .692 & 3.398 .636 & 3.307 .766 \\
\hline Total Aset & 3.201 .105 & 3.232 .644 & 4.964 .076 & 3.547 .023 & 3.517 .586 \\
\hline Liabilitas Jangka Pendek & 379.305 & 233.819 & 204.503 & 288.173 & 260.500 \\
\hline Liabilitas Jangka Panjang & 1.318 .504 & 1.444 .552 & 2.089 .557 & 2.114 .343 & 1.719 .106 \\
\hline Ekuitas & 1.503 .296 & 1.554 .303 & 2.670 .016 & 1.144 .507 & 1.537 .980 \\
\hline Pendapatan & 427.623 & 462.840 & 491.605 & 544.884 & 646.945 \\
\hline Laba Tahun Berjalan/EAT & $(95.845)$ & 51.007 & $(31.816)$ & $(1.547 .604)$ & $(168.518)$ \\
\hline Market Value Of Share & 660.000 & 810.000 & 570.000 & 450.000 & 372.000 \\
\hline Sumber :Anual Report GOZCO
\end{tabular}

Sumber : Anual Report GOZCO tahun 2013 - 2017 
Tabel 5. Ihtisar Keuangan PT. Jaya Agra Wattie Tbk Tahun 2013-2017 (jutaan rupiah)

\begin{tabular}{|l|r|r|r|r|r|}
\hline \multicolumn{1}{|c|}{ Uraian } & $\mathbf{2 . 0 1 3}$ & $\mathbf{2 . 0 1 4}$ & $\mathbf{2 . 0 1 5}$ & $\mathbf{2 . 0 1 6}$ & $\mathbf{2 . 0 1 7}$ \\
\hline \hline Persediaan & 53.654 & 51.902 & 86.574 & 51.018 & 51.647 \\
\hline Total Aset Lancar & 256.003 & 236.785 & 210.504 & 190.299 & 195.501 \\
\hline Total As et Tidak Lancar & 2.402 .825 & 2.825 .311 & 3.157 .648 & 3.100 .818 & 3.116 .981 \\
\hline Total Aset & 2.658 .827 & 3.062 .096 & 3.368 .152 & 3.291 .117 & 3.312 .482 \\
\hline Liabilitas Jangka Pendek & 395.989 & 447.982 & 451.499 & 645.953 & 1.274 .614 \\
\hline Liabilitas Jangka Panjang & 1.384 .666 & 1.303 .011 & 1.626 .712 & 1.594 .844 & 1.197 .889 \\
\hline Ekuitas & 1.274 .372 & 1.311 .103 & 1.289 .941 & 1.050 .319 & 839.979 \\
\hline Pendapatan & 648.516 & 760.611 & 658.309 & 590.138 & 555.140 \\
\hline Earning After Tax & 70.035 & 52.088 & $(11.716)$ & $(225.133)$ & $(199.929)$ \\
\hline Market Value Of Share & 1.434 .380 & 1.049 .363 & 830.431 & 479.385 & 936.122 \\
\hline
\end{tabular}

Sumber : Anual Report JAWA tahun 2013 - 2017

Tabel 6. Ihtisar Keuangan PT. London Sumatera Indonesia Tbk Tahun 20132017 (jutaan rupiah)

\begin{tabular}{|l|r|r|r|r|r|}
\hline \multicolumn{1}{|c|}{ Uraian } & $\mathbf{2 . 0 1 3}$ & $\mathbf{2 . 0 1 4}$ & $\mathbf{2 . 0 1 5}$ & $\mathbf{2 . 0 1 6}$ & $\mathbf{2 . 0 1 7}$ \\
\hline \hline Persediaan & 374.485 & 380.360 & 398.426 & 569.085 & 308.149 \\
\hline Total Aset Lancar & 1.999 .126 & 1.863 .506 & 1.268 .557 & 1.919 .661 & 2.168 .414 \\
\hline Total Aset Tidak Lancar & 6.039 .666 & 6.849 .568 & 7.580 .235 & 7.539 .427 & 7.575 .967 \\
\hline Total Aset & 8.038 .792 & 8.713 .074 & 8.848 .792 & 9.459 .088 & 9.744 .381 \\
\hline Liabilitas Jangka Pendek & 802.905 & 746.520 & 571.162 & 780.627 & 416.258 \\
\hline Liabilitas Jangka Panjang & 842.988 & 963.822 & 939.652 & 1.032 .477 & 1.205 .958 \\
\hline Ekuitas & 6.392 .899 & 7.002 .732 & 7.337 .978 & 7.645 .984 & 8.122 .165 \\
\hline Pendapatan & 4.113 .679 & 4.726 .539 & 4.189 .615 & 3.847 .869 & 4.738 .022 \\
\hline Earning After Tax & 768.625 & 929.405 & 623.309 & 592.769 & 763.423 \\
\hline Market Value Of Share & 13.162 .531 & 12.889 .732 & 9.002 .352 & 11.866 .737 & 9.684 .349 \\
\hline
\end{tabular}

Sumber : Anual Report LSIP tahun 2013 - 2017

Tabel 7. Ihtisar Keuangan PT. Salim Ivomas Pratama Tbk Tahun 2013-2017 (jutaan rupiah)

\begin{tabular}{|l|r|r|r|r|r|}
\hline \multicolumn{1}{|c|}{ Uraian } & $\mathbf{2 . 0 1 3}$ & $\mathbf{2 . 0 1 4}$ & $\mathbf{2 . 0 1 5}$ & $\mathbf{2 . 0 1 6}$ & $\mathbf{2 . 0 1 7}$ \\
\hline \hline Persediaan & 1.568 .496 & 1.773 .329 & 1.936 .731 & 2.070 .391 & 2.102 .762 \\
\hline Total Aset Lancar & 5.353 .269 & 6.010 .492 & 5.028 .025 & 5.729 .296 & 6.289 .818 \\
\hline Total Aset Tidak Lanc: & 22.711 .852 & 24.985 .559 & 26.669 .117 & 26.808 .296 & 27.107 .948 \\
\hline Total Aset & 28.065 .121 & 30.996 .051 & 31.697 .142 & 32.537 .592 & 33.397 .766 \\
\hline Liabilitas Jangka Pend & 6.460 .709 & 6.898 .825 & 5.373 .084 & 4.595 .300 & 6.187 .987 \\
\hline Liabilitas Jangka Panja & 5.906 .260 & 7.685 .096 & 9.092 .657 & 10.324 .004 & 9.029 .000 \\
\hline Ekuitas & 15.698 .152 & 16.412 .128 & 17.231 .401 & 17.618 .288 & 18.180 .779 \\
\hline Pendapatan & 13.279 .778 & 14.962 .727 & 13.835 .444 & 14.530 .938 & 15.826 .648 \\
\hline Earning After Tax & 604.801 & 1.138 .294 & 364.879 & 609.794 & 695.433 \\
\hline Market Value Of Shar & 12.238 .122 & 10.928 .424 & 5.146 .435 & 7.657 .647 & 7.192 .608 \\
\hline Sumber : Anual Report SIMP tahun & $2013-2017$ & & & \\
\hline
\end{tabular}

Sumber : Anual Report SIMP tahun 2013 - 2017 
Tabel 8. Ihtisar Keuangan PT. SMART Tbk Tahun 2013-2017 (jutaan rupiah)

\begin{tabular}{|l|r|r|r|r|r|}
\hline \multicolumn{1}{|c|}{ Uraian } & $\mathbf{2 . 0 1 3}$ & $\mathbf{2 . 0 1 4}$ & $\mathbf{2 . 0 1 5}$ & $\mathbf{2 . 0 1 6}$ & $\mathbf{2 . 0 1 7}$ \\
\hline \hline Persediaan & 3.365 .362 & 3.804 .054 & 3.389 .788 & 4.387 .631 & 4.501 .828 \\
\hline Total Aset Lancar & 8.079 .476 & 9.712 .926 & 10.680 .145 & 11.246 .586 & 11.163 .493 \\
\hline Total Aset Tidak Lancar & 10.301 .613 & 11.579 .960 & 13.276 .870 & 14.894 .824 & 15.960 .608 \\
\hline Total Aset & 18.381 .089 & 21.292 .886 & 23.957 .015 & 26.141 .410 & 27.124 .101 \\
\hline Liabilitas Jangka Pendek & 7.281 .549 & 8.996 .931 & 9.897 .188 & 8.356 .807 & 8.465 .263 \\
\hline Liabilitas Jangka Panjang & 4.624 .006 & 4.364 .466 & 6.437 .057 & 7.585 .168 & 7.358 .859 \\
\hline Ekuitas & 6.475 .534 & 7.931 .489 & 7.622 .770 & 10.999 .435 & 11.299 .979 \\
\hline Pendapatan & 23.935 .214 & 32.340 .665 & 36.230 .113 & 29.752 .126 & 35.318 .102 \\
\hline Earning After Tax & 892.772 & 1.477 .751 & $(385.509)$ & 2.599 .539 & 1.177 .371 \\
\hline Market Value Of Share & 22.546 .718 & 23.264 .766 & 12.063 .212 & 12.494 .041 & 9.822 .901 \\
\hline Sumber : Anual Report SMAR tahun $2013-2017$ & & & & \\
\hline
\end{tabular}

\subsection{Pembahasan/Analisis Kinerja Keuangan}

Analisis kinerja keuangan merupakan kegiatan untuk melihat sejauh mana suatu perusahaan telah melaksanakan dengan menggunakan aturan-aturan pelaksanaan keuangan secara baik.

\subsubsection{Analisis likuiditas}

Tingkat kemampuan perusahaan untuk memenuhi kewajiban jangka pendek dapat diketahui oleh analisis quick ratio. Berikut ini hasil perhitungan LTDtER.

Tabel 9. Hasil perhitungan Quick ratio

\begin{tabular}{lrrrrrr}
\hline \multirow{2}{*}{$\begin{array}{c}\text { Kode } \\
\text { Saham }\end{array}$} & \multicolumn{5}{c}{ Periode } & Rata- \\
\cline { 2 - 6 } & $\mathbf{2 0 1 3}$ & $\mathbf{2 0 1 4}$ & $\mathbf{2 0 1 5}$ & $\mathbf{2 0 1 6}$ & $\mathbf{2 0 1 7}$ & rata \\
\hline \hline AALI & 0,25 & 0,27 & 0,30 & 0,50 & 0,96 & 0,46 \\
BWPT & 0,90 & 0,42 & 0,63 & 0,44 & 0,29 & 0,54 \\
DNSG & 0,49 & 0,80 & 0,76 & 0,55 & 0,67 & 0,65 \\
GOZCO & 0,70 & 0,81 & 1,01 & 0,47 & 0,67 & 0,73 \\
JAWA & 0,51 & 0,41 & 0,27 & 0,22 & 0,11 & 0,31 \\
LSIP & 2,02 & 1,99 & 1,52 & 1,73 & 4,47 & 2,35 \\
SIMP & 0,59 & 0,61 & 0,58 & 0,80 & 0,68 & 0,65 \\
SMAR & 0,65 & 0,66 & 0,74 & 0,82 & 0,79 & 0,73 \\
\hline \hline
\end{tabular}

Sumber : Data diolah (2018)

Tabel 9 dapat dijelaskan bahwa kinerja likuiditas dari 8 perusahaan perkebunan kelapa sawit, hanya terdapat 1 perusahaan dengan kode saham (LSIP) yang mampu memenuhi kewajiban jangka pendek dengan aktiva lancar tanpa memperhitungkan persediaan ditunjukan oleh nilai rata-rata quick ratio sebesar 2,35 selama tahun 2013-2017. Sementara kinerja likuiditas 7 perusahaan lainnya dengan kode saham (AALI), (BWPT), (DNSG), (GOZCO), (JAWA), (SIMP), dan (SMAR) tidak mampu memenuhi kewajiban jangka pendek dengan aktiva lancar tanpa memperhitungkan persediaan, dengan nilai terendah dimiliki oleh perusahaan dengan kode saham JAWA ditunjukan oleh nilai rata-rata quick ratio sebesar 0,31 selama tahun 2013-2017.

\subsubsection{Analisis Leverage}

Tingkat kemampuan perusahaan untuk memenuhi kewajiban jangka panjang dapat diketahui oleh analisis leverage (Tabel 10). Tabel 10, dapat dilihat bahwa, kinerja leverage dari 8 perusahaan perkebunan kelapa sawit, hanya terdapat 1 perusahaan dengan kode saham (BWPT), yang tidak mampu memenuhi kewajiban panjang dengan modal sendiri ditunjukan oleh nilai rata-rata long term debt to equity ratio (LTDtER) sebesar 1,19 selama tahun 2013-2017. Sementara kinerja leverage 7 perusahaan lainnya dengan kode saham (AALI), (DNSG), (GOZCO), (JAWA), (LSIP), (SIMP) dan (SMAR) mampu memenuhi kewajiban panjang dengan modal sendiri, dengan nilai tertinggi dimiliki oleh perusahaan dengan kode saham (JAWA) ditunjukan oleh nilai rata-rata long term debt to equity ratio (LTDtER) sebesar 1,26 selama tahun 2013-2017. 
Tabel 10. Hasil perhitungan long term debt to equity ratio (LTDtER)

\begin{tabular}{lrrrrrr}
\hline \multirow{2}{*}{$\begin{array}{c}\text { Kode } \\
\text { Saham }\end{array}$} & \multicolumn{5}{c}{ Periode } & Rata- \\
\cline { 2 - 6 } & $\mathbf{2 0 1 3}$ & $\mathbf{2 0 1 4}$ & $\mathbf{2 0 1 5}$ & $\mathbf{2 0 1 6}$ & $\mathbf{2 0 1 7}$ & rata \\
\hline \hline AALI & 0,09 & 0,22 & 0,56 & 0,16 & 0,23 & 0,25 \\
BWPT & 1,58 & 0,91 & 1,06 & 1,22 & 1,20 & 1,19 \\
DNSG & 1,33 & 1,21 & 1,30 & 1,30 & 1,03 & 1,23 \\
GOZCO & 0,88 & 0,93 & 0,78 & 1,85 & 1,12 & 1,11 \\
JAWA & 1,09 & 0,99 & 1,26 & 1,52 & 1,43 & 1,26 \\
LSIP & 0,13 & 0,14 & 0,13 & 0,14 & 0,15 & 0,14 \\
SIMP & 0,38 & 0,47 & 0,53 & 0,59 & 0,50 & 0,49 \\
SMAR & 0,71 & 0,55 & 0,84 & 0,69 & 0,65 & 0,69 \\
\hline
\end{tabular}

Sumber : Data diolah (2018)

\subsubsection{Analisis Aktivitas}

Efisisiensi ativitas perusahaan untuk menghasilkan pendapatan dapat diketahui oleh analisis total asset turnover. Berikut ini hasil perhitungan TATO.

Tabel 11. Hasil perhitungan total aset turnover (TATO)

\begin{tabular}{lcccccc}
\hline \multirow{2}{*}{$\begin{array}{c}\text { Kode } \\
\text { Saham }\end{array}$} & \multicolumn{5}{c}{ Periode } & Rata- \\
\cline { 2 - 7 } & $\mathbf{2 0 1 3}$ & $\mathbf{2 0 1 4}$ & $\mathbf{2 0 1 5}$ & $\mathbf{2 0 1 6}$ & $\mathbf{2 0 1 7}$ & rata \\
\hline \hline AALI & 0,85 & 0,88 & 0,61 & 0,58 & 0,69 & 0,72 \\
BWPT & 0,25 & 0,14 & 0,15 & 0,16 & 0,19 & 0,18 \\
DNSG & 0,65 & 0,68 & 0,56 & 0,48 & 0,62 & 0,60 \\
GOZCO & 0,13 & 0,14 & 0,10 & 0,15 & 0,18 & 0,14 \\
JAWA & 0,24 & 0,25 & 0,20 & 0,18 & 0,17 & 0,21 \\
LSIP & 0,51 & 0,54 & 0,47 & 0,41 & 0,49 & 0,48 \\
SIMP & 0,47 & 0,48 & 0,44 & 0,45 & 0,47 & 0,46 \\
SMAR & 1,30 & 1,52 & 1,51 & 1,14 & 1,30 & 1,35 \\
\hline Sumber : Data diolah $(2018)$ & & & &
\end{tabular}

Tabel 11 dapat dijelaskan bahwa, aktivitas dari 8 perusahaan perkebunan kelapa sawit, hanya terdapat 1 perusahaan dengan kode saham (SMAR), dalam menghasilkan pendapatan sangat efektif, ditunjukan oleh rata-rata total assset turnover sebesar 1,35 selama tahun 2013-2017. Sementara aktivitas 7 perusahaan lainnya dengan kode saham (AALI), (BWPT), (DNSG), (GOZCO), (JAWA), (LSIP), dan (SIMP) dalam menghasilkan pendapatan kurang efektif, dengan nilai terendah dimiliki oleh perusahaan dengan kode saham (GOZCO) ditunjukan oleh rata-rata total assset turnover sebesar 0,14 selama tahun 2013-2017.

\subsubsection{Analisis Profitabilitas}

Kemampuan perusahaan untuk menghasilkan kentungungan dapat diketahui oleh analisis return of invesment. Berikut ini hasil perhitungan return of invesment (ROI).

Tabel 12. Hasil perhitungan return of invesment

\begin{tabular}{|c|c|c|c|c|c|c|}
\hline \multirow{2}{*}{$\begin{array}{c}\text { Kode } \\
\text { Saham } \\
\end{array}$} & \multicolumn{5}{|c|}{ Periode } & \multirow{2}{*}{$\begin{array}{r}\text { Rata- } \\
\text { rata }\end{array}$} \\
\hline & 2013 & 2014 & 2015 & 2016 & 2017 & \\
\hline AALI & 0,13 & 0,14 & 0,03 & 0,09 & 0,08 & 0,09 \\
\hline BWPT & $(0,00)$ & 0,01 & $(0,01)$ & $(0,02)$ & $(0,01)$ & $(0,01)$ \\
\hline DNSG & 0,04 & 0,09 & 0,04 & 0,03 & 0,07 & 0,05 \\
\hline GOZCO & $(0,03)$ & 0,02 & $(0,01)$ & $(0,44)$ & $(0,05)$ & $(0,10)$ \\
\hline JAWA & 0,03 & 0,02 & $(0,00)$ & $(0,07)$ & $(0,06)$ & $(0,02)$ \\
\hline LSIP & 0,10 & 0,11 & 0,07 & 0,06 & 0,08 & 0,08 \\
\hline SIMP & 0,02 & 0,04 & 0,01 & 0,02 & 0,02 & 0,02 \\
\hline SMAR & 0,05 & 0,07 & $(0,02)$ & 0,10 & 0,04 & 0,05 \\
\hline
\end{tabular}


Pada Tabel 12 dilihat bahwa, Kinerja profitabilitas dari 8 perusahaan perkebunan kelapa sawit, hanya terdapat 3 perusahaan dengan kode saham (BWPT), (GOZCO), dan (JAWA), kurang memberikan keuntungan, bahkan mengalami kerugian, dengan nilai terendah dimiliki oleh perusahaan dengan kode saham (BWPT), ditunjukan oleh rata-rata Return of invesment (ROI) sebesar 0,01. selama tahun 2013-2017. Sementara Kinerja profitabilitas 5 perusahaan lainnya dengan kode saham (AALI), (DNSG), (LSIP), (SMAR), dan (SIMP) juga kurang mmberikan keuntungan tetapi tidak sampai mengalami kerugian, dengan nilai tertinggi dimiliki oleh perusahaan dengan kode saham (AALI) ditunjukan oleh rata-rata Return of invesment (ROI) sebesar 0,09 selama tahun 2013-2017.

\subsubsection{Analisis Nilai Perusahaan}

Nilai perusahaan dapat dijelaskan tobin's Q. Berikut ini hasil perhitungan tobin's Q.

Tabel 13. Hasil perhitungan tobin's q

\begin{tabular}{|c|c|c|c|c|c|c|}
\hline \multirow{2}{*}{$\begin{array}{c}\text { Kode } \\
\text { Saham }\end{array}$} & \multicolumn{5}{|c|}{ Periode } & \multirow{2}{*}{$\begin{array}{c}\text { Rata- } \\
\text { rata }\end{array}$} \\
\hline & 2013 & 2014 & 2015 & 2016 & 2017 & \\
\hline$\overline{\mathrm{AALI}}$ & 2,84 & 2,29 & 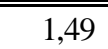 & $1,1,44$ & $\bar{~} 1,10$ & 1,83 \\
\hline BWPT & 1,35 & 1,25 & 0,71 & 1,06 & 0,91 & 1,06 \\
\hline DNSG & 1,17 & 1,48 & 1,20 & 1,17 & 0,96 & 1,19 \\
\hline GOZCO & 0,65 & 0,71 & 0,53 & 0,76 & 0,61 & 0,65 \\
\hline JAWA & 1,11 & 0,84 & 0,80 & 0,77 & 0,97 & 0,90 \\
\hline LSIP & 1,59 & 1,46 & 1,04 & 1,24 & 0,94 & 1,26 \\
\hline SIMP & 0,69 & 0,63 & 0,46 & 0,52 & 0,48 & 0,56 \\
\hline SMAR & 1,43 & 1,26 & 0,74 & 0,66 & 0,53 & 0,93 \\
\hline
\end{tabular}

Pada tabel 13 dilihat bahwa terdapat 4 Nilai Perusahaan dengan kode saham (AALI), (BWPT), (DNSG), dan (LSIP) dari aspek pasar atau investor memiliki prospek investasi yang tinggi, dengan nilai tertinggi dimiliki oleh perusahaan dengan kode saham (AALI), ditunjukan oleh rata-rata tobins' $q$ sebesar 1,83 selama tahun 2013-2017. Sementara terdapat juga 4 Nilai Perusahaan dengan kode saham (GOZCO), (JAWA), (SIMP), dan (SMAR) dari aspek pasar atau investor memiliki potensi pertumbuhan yang rendah, dengan nilai terendah dimiliki oleh perusahaan dengan kode saham (SIMP), ditunjukan oleh rata-rata tobins'q sebesar 0,56 selama tahun 2013-2017.

\subsubsection{Intepretasi Kinerja Keuangan terhadap Saham}

\section{a. Uji T}

Tabel 14. Coefficients Uji T

\begin{tabular}{ccr}
\multicolumn{3}{c}{ Coefficients $^{\mathbf{a}}$} \\
\hline Model & $\mathrm{t}$ & \multicolumn{1}{c}{ Sig. } \\
\hline \hline Quick Ratio & $-3,747$ &, 001 \\
LTDtER & $-4,239$ &, 000 \\
Total Assets & 2,379 &, 023 \\
Turnover & $-1,616$ &, 115 \\
ROI & 7,270 &, 000 \\
Tobin's Q & & \\
\hline a. Dependent Variable: Harga Saham & \\
Sumber : Output IBM SPSS Statistics 23 for Windows, 2018
\end{tabular}

Tabel 14, Uji T menunjukkan signifikansi quick ratio sebesar 0,001<0,05, sehingga variabel $\mathrm{X}_{1}$ (quick ratio) berpengaruh secara parsial terhadap variabel Y (harga saham). Signifikansi LTDtER sebesar $0,000<0,05$ sehingga variabel $\mathrm{X}_{2}(L T D t E R)$ berpengaruh secara parsial terhadap variabel $\mathrm{Y}$ (harga saham). Signifikansi TATO sebesar 0,023<0,05, sehingga variabel $\mathrm{X}_{3}$ (Total Assets Turnover) berpengaruh secara parsial terhadap variabel Y (harga saham). Signifikansi ROI sebesar 0,115>0,05, sehingga variabel $\mathrm{X}_{4}(R O I)$ tidak berpengaruh secara parsial terhadap variabel $\mathrm{Y}$ (harga saham). Signifikansi tobin's $Q$ sebesar $0,000<0,05$, sehingga variabel $X_{5}$ (Tobin's $Q$ ) berpengaruh secara parsial terhadap variabel $Y$ (harga saham). 


\section{b. UJI F}

Tabel 15. Anova Uji F

\begin{tabular}{clcc}
\multicolumn{4}{c}{ ANOVA $^{\mathrm{a}}$} \\
\hline & Model & $\mathrm{F}$ & Sig. \\
\hline \multirow{2}{*}{1} & $\begin{array}{l}\text { Regression } \\
\text { Residual } \\
\text { Total }\end{array}$ & 26,539 &, $000^{\mathrm{b}}$ \\
& & \\
\hline \hline a. harga saham \\
Sumber : Output IBM SPSS Statistics 23 for Windows, 2018
\end{tabular}

Berdasarkan Tabel 15, hasil Uji $\mathrm{F}$ menunjukkan, tingkat signifikansi sebesar 0,000 0,05. sehingga variabel $\mathrm{X}_{1}$ (quick ratio), $\mathrm{X}_{2}$ (long term debt to equity ratio/LTDtER), $\mathrm{X}_{3}$ (total assets turnover), $\mathrm{X}_{4}$ (return of invesment /ROI), dan $\mathrm{X}_{5}$ (Tobins'Q) secara bersama-sama memiliki pengaruh yang signifikan terhadap variabel $Y$ (harga saham).

\section{PENUTUP}

\subsection{KESIMPULAN}

Berdasarkan hasil penelitian, dapat disimpulkan bahwa dari aspek :

- PT. London Sumatera Indonesia Tbk (LSIP) satu-satunya perusahaan yang likuiditas, dengan ratarata quick ratio $>1$ sebesar 2,35

- PT. Astra Agro Lestari Tbk (AALI), PT. London Sumatera Indonesia Tbk (LSIP), PT. Salim Ivomas Pratama Tbk (SIMP) dan PT. SMART Tbk (SMAR) merupakan perusaha leverage, masing-masing memiliki rata-rata LTDR $>1$

- PT. SMART Tbk (SMAR) merupakan perusahaan yang mempunyai aktivitas yang efisien, rata-rata nilai TATO sebesar 1,35.

- Rata-rata Profitabilitas perusahaan kelapa sawit kurang memberikan keuntungan nilai return of invesment < 0,3. BWPT., GOZCO dan JAWA merupakan perusahaan rata-rata mengalami kerugian

- Nilai perusahan yang tinggi di mata pasar adalah AALI, BWPT. , DNSG, LSIP memiliki tobin's q> 1.

- kinerja keuangan yang diproksikan dengan quick ratio, LTDtER, TATO, ROI maupun nilai perusahaan secara bersama-sama mempunyai pengaruh terhadap nail dan turun harga saham dengan tingkat sig $0,000<0,05$.

\subsection{SARAN}

Hasil penelitian menunjukkan rata-rata kinerja perusahaan mengalami penurunan kinerja, diharapkan pihak manajemen perusahaan meningkatkan kinerjanya dengan strategi yang efektif dan efisien.

\section{DAFTAR PUSTAKA}

Arifin. 2007. Teori Keuangan Dan Pasar Modal. Ekonisia. Yogyakarta

Barus., A., M., dkk. 2017. Penggunaan Rasio Keuangan Untuk Mengukur Kinerja Keuangan Perusahaan (studi pada PT. Astra Otoparts, Tbk dan PT. . Goodyer Indonesia Tbk Yang Go Publik di Bursa Efek Indonesia). Jurnal. Fakultas Ilmu Administrasi. Universitas Brawijaya. Malang. Vol 44 No 1 Maret 2017.

Chung, K.H and Pruitt, S.W, 1994. A Simple Approximation of Tobin's q, Financial Management, Vol. 23, No.3

Fahmi, I. 2014. Analisis Laporan Keuangan. Alfabeta. Bandung.

Ghozali, Imam. (2016). Aplikasi Analisis Multivariate dengan Program IBM SPSS 23. BPFE Universitas Diponegoro. Semarang.

Hanafi, M., M. \& Halim, A. 2014. Analisis Laporan Keuangan. UPP STIM YKPN. Yogyakarta

Hery, S.E., M.Si. 2015. Analisis Laporan Keuangan : Pendekatan Rasio Keuangan. PT. . Buku Seru. Yogyakarta.

Isaskar, R. 2012. Buku ajar "Manajemen Keuangan : Rasio Keuangan". Lab. Manajemen Agribisnis, Faculty of Agriculture, Universitas Brawijaya. Malang. 
Jumingan. 2017. Analisa Laporan Keuangan. Bumi Aksara. Jakarta

Kasmadi \& Sunariah., N., S. 2014. Metode Penelitian Kuantitatif. Alfabeta. Bandung

Kasmir, 2014. Analisis Laporan Keuangan. Edisi Pertama. Cetakan Kedelapan. PT. . Raja Grafindo Persada. Jakarta

Khotib, M. 2018. Analisa Nilai Perusahaan. Rubik Pembebasan. Ternate

Reeve, J., M., Dkk. 2010. Pengantar Akuntansi AdaPT. asi Indonesia : Principles Of Accounting - Indonesia AdaPT. ion. Terjemahan Dian., D. Salemba Empat. Jakarta.

Sartono, A. 2011. Manajemen Keuangan (Teori dan Aplikasi). BPFE. Yogyakarta.

Sujarweni, W., V. 2017. Analisis Laporan Keuanagan : Teori, Aplikasi \& Hasil Penelitian. Pustaka Baru Press. Yogyakarta

Smithers. Andrew \& Wright. Stephen., 2007. Valuing Wall Street, McGraw Hill Education. New York

Widiatmojo, S. 2005. Cara Sehat Investasi Di Pasar Modal. Media Komputindo. Jakarta.

Weston, J. Fred dan Copeland, Thomas E. 2001. Manajemen Keuangan Jilid I, Edisi ke-9. Jakarta: Binarupa Aksara.

2018. Panduan Penyusunan Skripsi/PKL. Fakultas Pertanian. Universitas Muhammadiyah. Ternate

http:// www.idx.co.id. diakses tangal 10/10/2017 \& 12/12/2018. 